This document was prepared in conjunction with work accomplished under Contract No. DE-AC09-96SR18500 with the U. S. Department of Energy.

\title{
DISCLAIMER
}

This report was prepared as an account of work sponsored by an agency of the United States Government. Neither the United States Government nor any agency thereof, nor any of their employees, makes any warranty, express or implied, or assumes any legal liability or responsibility for the accuracy, completeness, or usefulness of any information, apparatus, product or process disclosed, or represents that its use would not infringe privately owned rights. Reference herein to any specific commercial product, process or service by trade name, trademark, manufacturer, or otherwise does not necessarily constitute or imply its endorsement, recommendation, or favoring by the United States Government or any agency thereof. The views and opinions of authors expressed herein do not necessarily state or reflect those of the United States Government or any agency thereof.

This report has been reproduced directly from the best available copy.

Available for sale to the public, in paper, from: U.S. Department of Commerce, National Technical Information Service, 5285 Port Royal Road, Springfield, VA 22161, phone: (800) 553-6847, fax: (703) 605-6900

email: orders@ntis.fedworld.gov

online ordering: http://www.ntis.gov/help/index.asp

Available electronically at http://www.osti.gov/bridge

Available for a processing fee to U.S. Department of Energy and its contractors, in paper, from: U.S. Department of Energy, Office of Scientific and Technical Information, P.O. Box 62, Oak Ridge, TN 37831-0062,

phone: (865)576-8401,

fax: (865)576-5728

email: $\underline{\text { reports@ adonis.osti.gov }}$ 


\section{REPAIR OF A MELTER POUR SPOUT USING AN EXPANDING RING ${ }^{\dagger}$}

\author{
Harold B. Peacock \\ Kenneth J. Imrich \\ Poh-Sang Lam \\ Douglas R. Leader
}

\section{Savannah River Technology Center Westinghouse Savannah River Site Aiken, South Carolina 29808}

\author{
Daniel C. Iverson
}

\section{ABSTRACT}

An expanding ring was developed that provided remote repair of the pour spout for a radioactive waste vitrification melter. This passive device used gas pressure to expand a metal ring against the irregularly shaped pour spout wall. Laboratory modeling and testing were performed for proof of concept and optimization before final design and field deployment. The ring expanded radially more than $4.8 \mathrm{~mm}$ and successfully repaired the melter pour spout allowing continued glass pouring operation.

\section{INTRODUCTION}

The Defense Waste Processing Facility (DWPF) vitrifies high level radioactive waste (HLW) from waste tanks at Savannah River Site (SRS). The process produces a suitable waste form for long-term dry storage of the HLW. Initially the chemistry of the liquid HLW is adjusted using various acids. Borosilicate glass frit is added, the slurry is condensed, and then it is fed into a high temperature glass melter. When melted the molten glass is poured into stainless steel canisters. Over the years, flow of molten glass down the pour spout has corroded the glass disengagement point to the extent that the stream could no longer be directed into the stainless steel storage canister without plugging.

The melter is operated within facility referred to as a canyon. The facility incorporates $1.4 \mathrm{~m}(4.5 \mathrm{ft})$ thick concrete walls to shield personnel from the radioactive waste. A significant engineering challenge exists for any modification or repair because all operations must be performed remotely. To repair the pour spout a simple and novel technique was developed that allows a circumferential seal against the pour spout wall. The expanding ring will seal against an irregular shaped surface. This pressurized device is remotely deployable requiring no complicated mechanical tooling to install. The ring is positioned into the heated section of the pour spout and allowed to expand. This paper describes the expanding ring developed for the melter pour spout repair.

† Patent Pending

\author{
Defense Waste Processing Facility \\ Westinghouse Savannah River Site \\ Aiken, South Carolina 29808
}

\section{BACKGROUND}

Approximately 136 million liters (36 million gallons) of highly radioactive waste solutions from the production of nuclear materials at the United States Department of Energy's Savannah River Site (SRS) are presently stored in large underground carbon steel tanks. SRS is closing the tank farm and dispositioning the inventory of high level waste. Vitrication technology was developed on site for immobilizing waste to allow for controlled decay of long-lived radionuclides and will be used to treat the waste solution.

Liquid high level waste sludge is transferred from waste tanks to the Defense Waste Processing Facility (DWPF). First the chemistry is adjusted by addition of nitric and formic acids. Borosilicate frit is then added and the slurry is concentrated until a solids content of 45 to $50 \mathrm{wt} \%$ is attained. The slurry is finally fed to a melter where it is melted. The resultant high level waste glass is poured into stainless steel canisters, which is part of the engineering package that will be used for long-term storage of the HLW.

DWPF's first glass melter began operation in May 1994 and was shut down for replacement in November 2002. It operated continuously for over eight years, including 2 years of non-radioactive cold chemical operations followed by 6 years of radioactive waste processing. Over 1400 canisters, $2.4 \times 10^{6} \mathrm{~kg}$ (5.2 million pounds) of glass, have been successfully poured. This represents about 27 percent of the total glass to be produced in this facility.

The DWPF Melter (Figure 1) is a refractory lined cylindrical vessel. Heat is provided via Joule heating of the glass and by resistance heaters located in the melter plenum, riser, pour spout, and drain valve. Internal dimensions are approximately $1.83 \mathrm{~m}(6 \mathrm{ft})$ diameter by $2.2 \mathrm{~m}(7 \mathrm{ft})$ high. Nominal glass depth is $86 \mathrm{~cm}$ (34 in). Glass contact material is Monofrax ${ }^{\mathrm{TM}} \mathrm{K}-3$, a fused-cast chromia-alumina refractory. Vapor space refractory is Korundal ${ }^{\mathrm{TM}} \mathrm{XD}$. Metal components in contact with the molten glass and vapor space were fabricated from a nickel-base alloy, Inconel ${ }^{\mathrm{TM}}$ 690. These include thermowells, a bubbler, off gas film coolers, lid heaters, borescopes, electrodes, and the pour spout. 


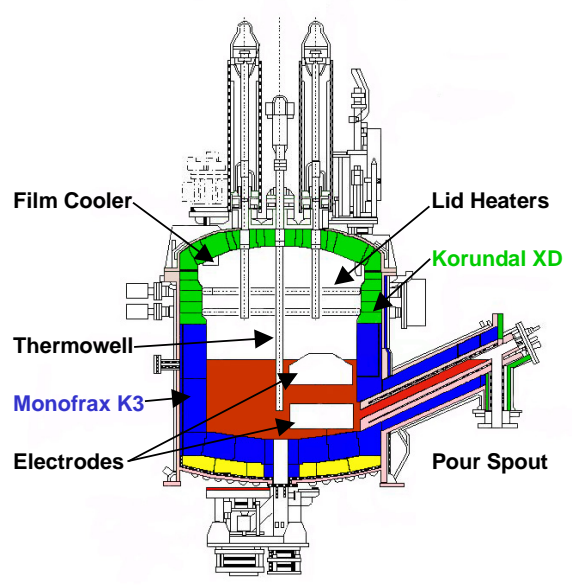

Figure 1. Schematic of the DWPF melter.

The melter is operated at a glass temperature of approximately $1150{ }^{\circ} \mathrm{C}$. Once the slurry containing the borosilicate frit is melted the molten glass flows up the melter riser where it then flows down the pour spout into a stainless steel waste canister below. Two machined circumferential steps (upper and lower knife edges) in the pour spout are intended to allow the molten glass to disengage the pour spout and fall freely into the center of the canister (Figure 2). The knife edges, located at the 5 to $7.6 \mathrm{~cm}$ ( 2 to $3 \mathrm{inch}$ ) transition and the 7.6 to $10 \mathrm{~cm}$ ( 3 to 4 inch) transition, are maintained at $1100{ }^{\circ} \mathrm{C}$ with external heaters. The lower most $10 \mathrm{~cm}$ (4 inch) section has a temperature gradient from $1100{ }^{\circ} \mathrm{C}$ at the lower knife edge to approximately $500{ }^{\circ} \mathrm{C}$ at the bottom. Molten glass wets only about $30 \%$ of the circumference of the pour spout. When the pour stream detaches from the upper knife edge it must fall through a non-heated portion of the pour spout before reaching the canister.

After approximately 3 years of operation, glass pouring problems led to remote visual inspection of the melter pour spout. This was accomplished by the use of a high temperature remotely operated borescope. Examination revealed significant material loss on the glass contact side of the pour spout (Figure 3). This figure represents a 360 degree panoramic view of the pour spout bore, showing the extent of material loss, estimated to be $6.4 \mathrm{~mm}(0.25 \mathrm{in})$ at the upper knife edge. This condition resulted in a significant reduction in melter throughput due to the frequent need for cleaning glass from the lower spout. The need to reestablish desired glass flow characteristics led to the development of remote cleaning tools, the nickel 200 bellows liner, and the replaceable pour spout insert. The nickel liner was installed because it shed molten glass better than the 304L liner ${ }^{(1)}$. The insert acted as a funnel by collecting the molten glass and allowing it to fall into the center of the canister once more. It also protected the 3 inch bore from further degradation. Subsequent metallurgical examination of a degraded insert established a nominal corrosion rate $4.78 \mathrm{~mm} / \mathrm{yr}(0.188 \mathrm{in} / \mathrm{yr})$ and the mechanism for the observed $\operatorname{attack}^{(2)}$.

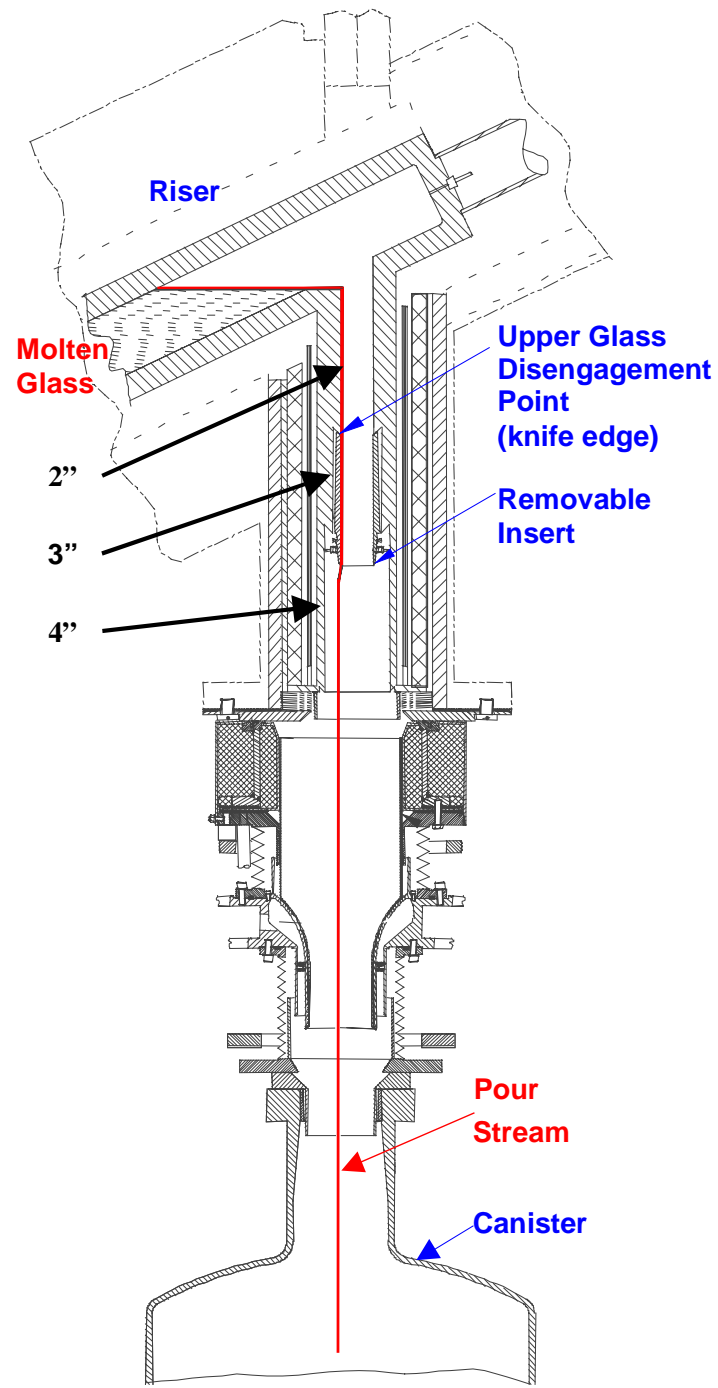

Figure 2. Melter pour spout showing the upper glass disengagement point.

Approximately seven years later the removable insert would no longer redirect the glass as desired and melter throughput suffered. Inspection of the upper portion of the 3 inch diameter bore showed that it had become elliptical with a major diameter of approximately $8.25 \mathrm{~cm}$ (3.25 inches). The

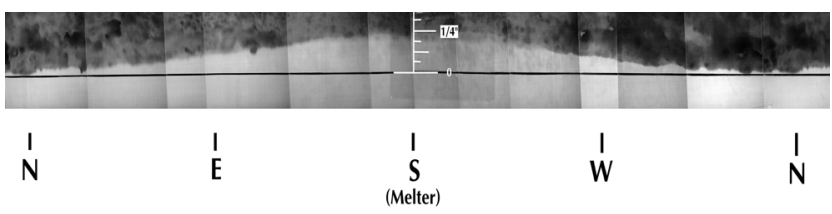

Figure 3. 360 degree panoramic view of the melter pour spout showing metal loss at the upper knife edge $(\mathrm{S})$.

metal surface was also extremely rough. The observed degradation resulted because the $5 \mathrm{~cm}$ ( 2 inch) bore continued to experience material loss in the glass contact region. Thus the insert would no longer seal underneath the upper knife edge (Figure 2). The pour stream split with some going 
behind the insert. The resulted in further corrosion of the pour spout wall. The portion of the pour stream that remained attached to pour spout wall solidified in the lower unheated section and eventually blocked glass flow into the canister.

Several unsuccessful attempts were made using special inserts and platinum gaskets to seal against the upper knife edge. Successful repair of the pour spout was only accomplished by using an expanding ring to produce an active, circumferential seal against the wall.

\section{EXPANDING RING DEVELOPMENT}

The following design requirements were imposed for development and for installation of the expanding ring into the fully operational DWPF melter pour spout.

1) The ring had fit into the $7.6 \mathrm{~cm}$ (3 inch) bore and have a $5 \mathrm{~cm}$ ( 2 inch) inner diameter. It had to expand at least a $0.32 \mathrm{~cm}(0.125 \mathrm{inch})$ radially with the capability to expand an additional $0.76 \mathrm{~mm}$ (0.030 inch) into a contoured gouge which was designed to represent the degradation on the glass contact side of the pour spout.

2) Provide sufficient force necessary to make a permanent glass tight seal but not deform the pour spout wall.

3) Time to insert and position ring into the pour spout before expanding must be at least three minutes.

4) All materials must be compatible with existing materials and the corrosive environment (glass and vapor).

The expanding ring consists of an inner and outer ring as shown in Figure 4. The rings were machined so there is a

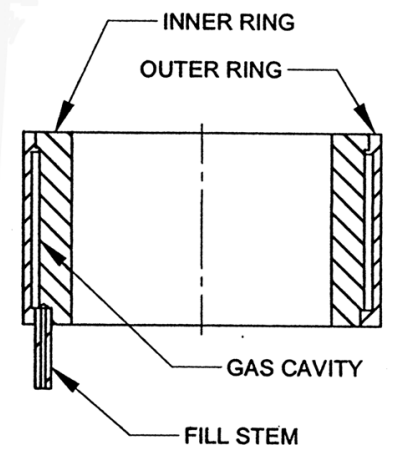

Figure 4. Expanding Ring Concept

small internal cavity. The inner and outer rings are electronbeam welded to provide a full penetration weld. The internal cavity is purged of residual moisture and then filled with pressurized helium gas through the attached fill stem. After pressurizing the fill stem is pinch welded to seal the gas inside the chamber. Helium was chosen as the fill gas primarily because it made leak detection after fabrication easy. The diffusivity of helium gas in face-centered-cubic metals at high temperature is low; therefore, a positive pressure would be maintained for a longer period of time.

The wall thickness of the inner and outer ring, for this application, is designed so the stress in the outer ring is larger in order to cause deformation or bulging of the surface. Permanent deflection occurs when the stress due to the internal pressure exceeds the material yield stress at temperature.

The gas pressure is calculated using the Ideal Gas Law, which is a function of cavity volume and temperature. The relationship between pressure, volume and temperature is given by:

$$
\frac{\mathrm{P}_{1} \mathrm{~V}_{1}}{\mathrm{~T}_{1}}=\frac{\mathrm{P}_{2} \mathrm{~V}_{2}}{\mathrm{~T}_{2}}
$$

where subscript 1 refers to initial conditions and subscript 2 refers to conditions at temperature.

\section{FINITE ELEMENT MODELING}

Finite element modeling was used to aid ring design by investigating the deformation characteristic as a function of increasing temperature and by determining the stress distribution in the ring and pour spout wall. Axisymmetric models of the ring and the DWPF pour spout were constructed and analyzed using the ABAQUS computer code ${ }^{(3)}$. The temperature dependent stress-strain characteristics of Inconel 690 were obtained from the literature ${ }^{(4,5)}$. The material was considered nearly perfectly plastic at $1050{ }^{\circ} \mathrm{C}$.

As the ring temperature increases the gas pressure increases until the material reaches its yield strength. The outer wall of the ring then expands until the pressure is no longer sufficient to cause yielding of additional material. The final stress distribution from a typical cross-section from the model of an expanding ring against the pour spout wall is shown in Figure 5. The initial gas fill pressure was $2.76 \mathrm{kPa}$
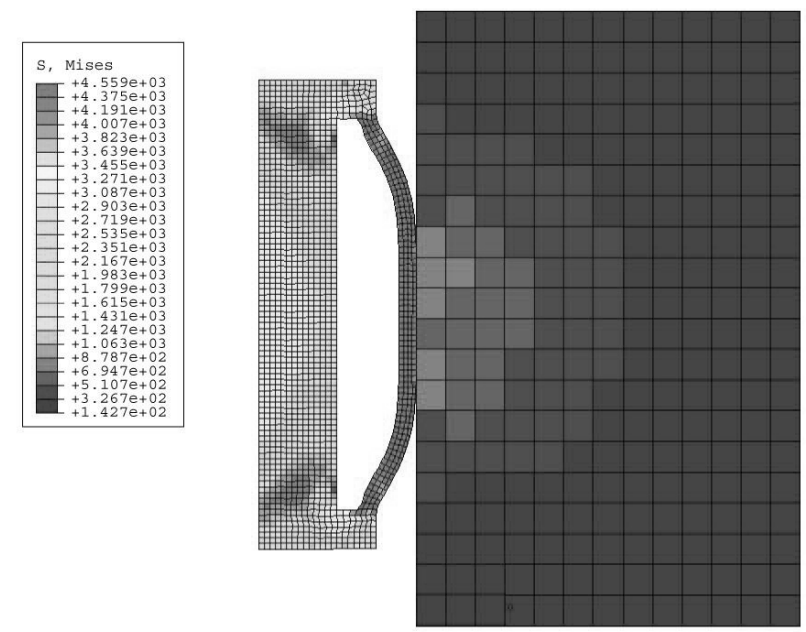

Figure 5. Mises stress results from the finite element analysis of an axisymmetric Inconel 690 model with an initial $3.2 \mathrm{~mm}$ (1/8 $\mathrm{inch})$ radial clearance between the ring and wall.

(400 psig) at room temperature, and the initial gas volume was $10.3 \mathrm{~cm}^{3}\left(0.63 \mathrm{in}^{3}\right)$.

For the $1.6 \mathrm{~mm}(1 / 16 \mathrm{inch})$ outer wall, the ring yields at a calculated Mises stress of about $31.7 \mathrm{kPa}$ (4600 psi). The maximum stress level for the $3 / 8$ inch inner ring wall was calculated to be less than $20.7 \mathrm{kPa}$ (3000 psi). When fully 
expanded, the stress on the pour spout wall was approximately $6.9 \mathrm{kPa}(1000 \mathrm{psi})$ at the contact area.

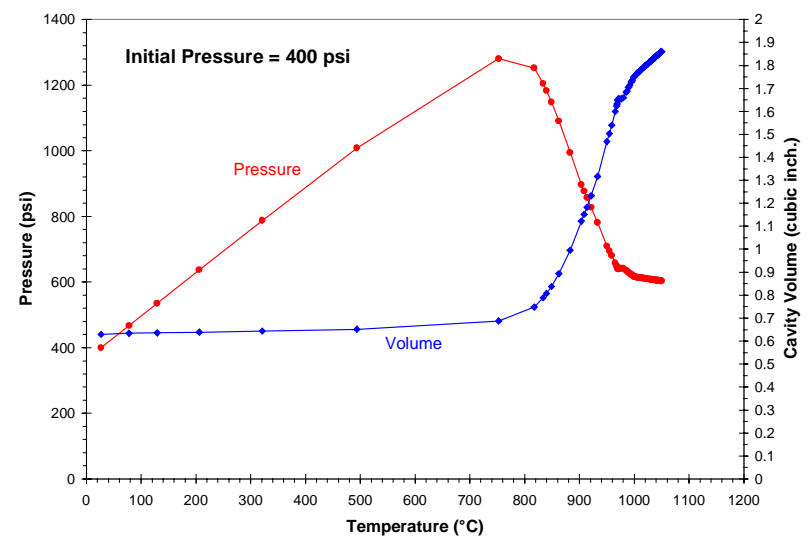

Figure 6. Calculated pressure and cavity volume changes as a function of temperature for the expanding ring.

Ring pressure and expansion as a function of temperature were calculated using ABAQUS and are shown in Figure 6. Internal gas pressure increases with temperature until the material yields at approximately $800{ }^{\circ} \mathrm{C}$. At this temperature the cavity begins to expand. Above $800{ }^{\circ} \mathrm{C}$, the pressure decreases rapidly as the cavity becomes larger. At approximately $960^{\circ} \mathrm{C}$, the outer surface reaches the wall. With increasing temperature, the cavity continues to expand, flattening against the wall. Finally, the membrane stress becomes less than the yield strength and no further expansion occurs.

\section{EXPERIMENTAL TESTING}

The expanding ring was developed and tested in a massive Glo-Bar ${ }^{\mathrm{TM}}$ furnace in the Materials Laboratory prior to deployment in the field. An Inconel 690 ring and pour spout assembly was tested with a maximum radial clearance of $0.4763 \mathrm{~cm}(0.1875 \mathrm{inch})$. An additional $0.76 \mathrm{~mm}(0.030 \mathrm{inch})$ was machined in a region of the pour spout mockup of about 30 degrees around the circumference to simulate the contour of the degraded pour spout. No attempt was made to duplicate surface roughness in laboratory tests. The simulated pour spout was coated with molten glass prior to ring insertion to approximate field conditions.

An assembled ring used in the testing program is shown in Figure 7. Type $\mathrm{K}$ thermocouples were attached to the ring to
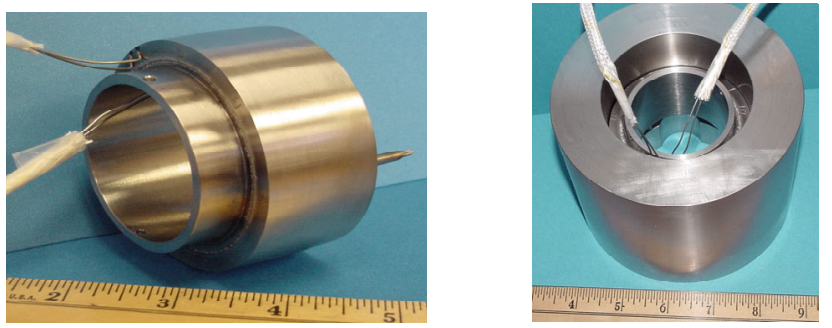

Figure 7. Pressurized Inconel 690 expanding ring with fill stem and attached thermocouples (left). Ring inserted into simulated pour spout (right). measure temperature, which was recorded by a data acquisition system at 1 second intervals.

\section{TEST RESULTS}

A graph of displacement versus time for an actual test and that predicted by the finite element model is shown in Figure

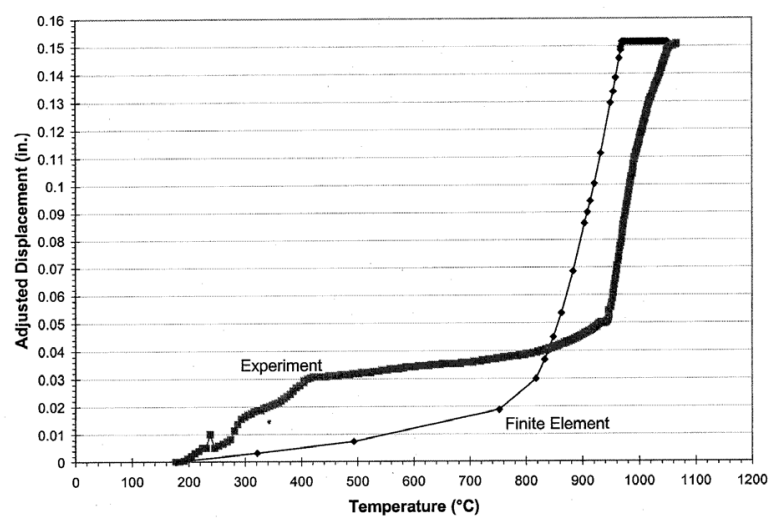

Figure 8. Experimental and calculated ring expansion for $1 / 8$ inch radial gap including 0.03 inch contoured groove.

8. Although there was a slight difference initially between the measured and predicted data, which was attributed to the measuring system, finite element modeling was useful for predicting expansion rates of modified designs.

Multiple tests were performed to optimize radial expansion, axial contact, expansion rates, and the force exerted on pour spout wall. In addition, sealing capability and removal force for both a pressurized ring and a ring that was installed but depressurized were evaluated. The maximum radial expansion tested was $0.6 \mathrm{~cm}$ (0.218 inches) with an axial contact of $2 \mathrm{~cm}$ ( 0.75 inches). Time to begin expansion ranged from 3 to 6 minutes depending on the design. Static loads up to $32 \mathrm{~kg}$ (70 lbs) were required to initiate ring movement. A significantly higher load, $154 \mathrm{~kg}$ (340 lbs), was required to start movement after extended elevated temperature exposure. To test the seal additional glass frit was placed on top of the ring after it had been expanded. The assembly was allowed to soak in the furnace for several more hours before evaluation. Molten glass did not seep past the seal even in the contoured gouge (Figures 9 and 10). It was
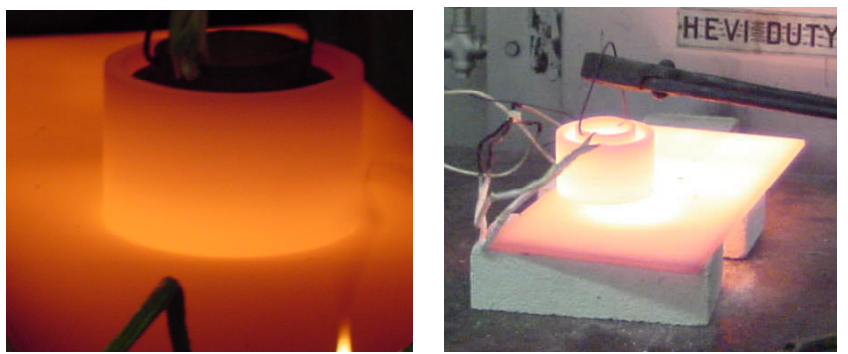

Figure 9. Photographs of expanding ring after being installed in simulated pour spout (left) and after removal from furnace (right). 


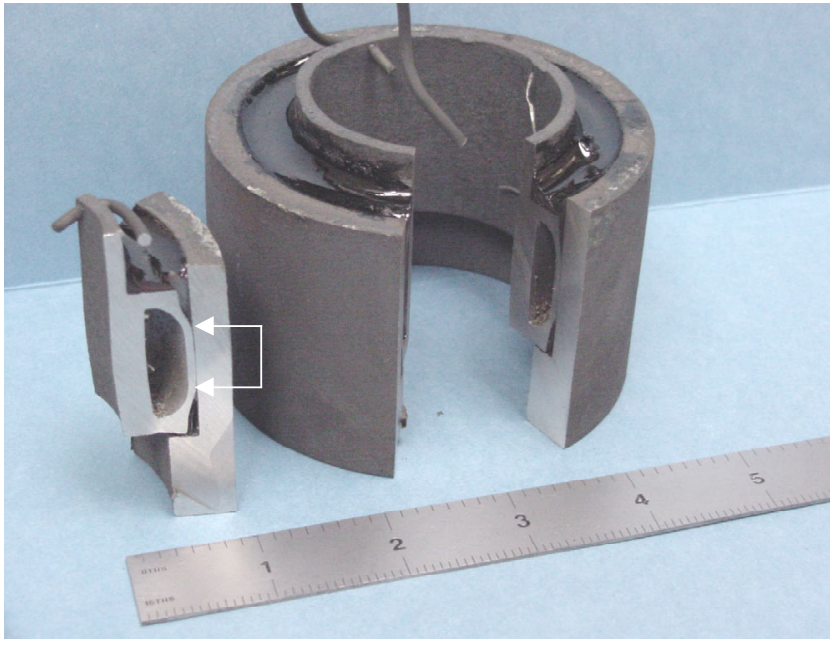

Figure 10. Destructive evaluation of ring/simulated pour spout assembly with $0.159 \mathrm{~cm}(1 / 16 \mathrm{inch})$ radial clearance after static molten glass exposure. Total axial contact was $2 \mathrm{~cm}$ (0.75 inches) (see arrow).

found that even a depressurized ring would still seal effectively and required significant force to initiate movement.

\section{FIELD DEPLOYMENT}

After proof of principal testing was completed the expanding ring was deployed to the field. Special tooling was developed to remotely position the expanding ring into the melter pour spout. This was accomplished by using a remote telerobotic arm (TRM) equipped with video cameras that could reach $3.7 \mathrm{~m} \mathrm{(12} \mathrm{feet)} \mathrm{to} \mathrm{the} \mathrm{melter} \mathrm{pour} \mathrm{spout.}$ Installation went as planned with insertion and positioning at the upper knife edge taking less than a minute. The expanding ring was allowed to soak for at least $1 / 2$ hour at $1100{ }^{\circ} \mathrm{C}$ to ensure an adequate circumferential seal had been obtained

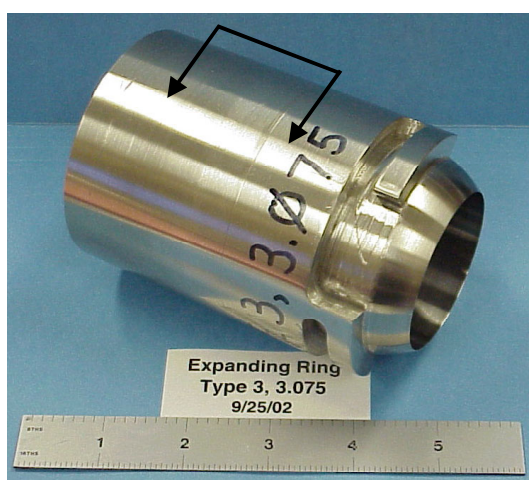

Figure 11. Photograph of completed expanding ring assembly including lower ball joint for mating insert. Expanding ring portion is shown between arrows.

before initiating glass pouring. The pour stream was stable and directed the molten glass into the canister. There was no indication of significant glass flow behind the expanding ring and insert. Figure 11 shows fully fabricated and charged expanding ring assembly prior to deployment to the field.

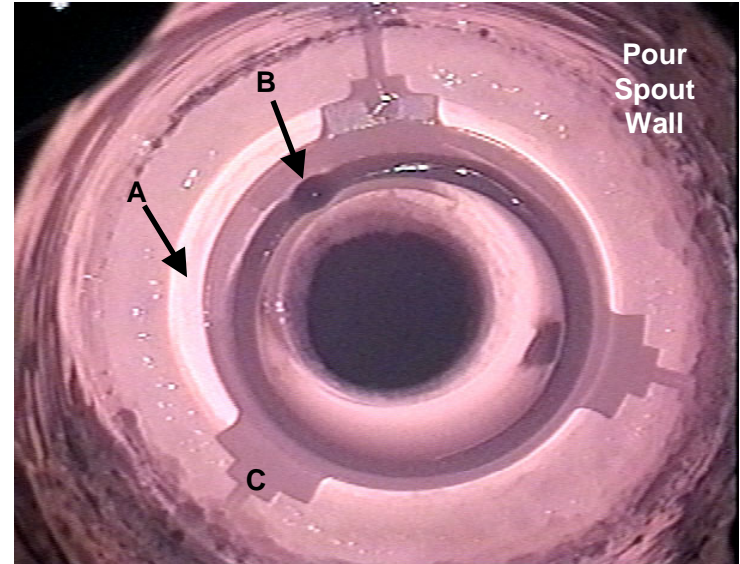

Figure 12. Remote video image taken off-center of the DWPF melter pour spout showing the expanding ring and insert installed after several glass pours. A) Expanded ring, B) Mating removable insert with residual glass at disengagement point, C) Insert retaining pins.

Figure 12 shows a photograph of the ring installed in the pour spout during an inspection after glass pouring operations had resumed.

\section{CONCLUSIONS}

Based on the results of the laboratory testing and field implementation the conclusions are:

1) The expanding ring successfully created a glass tight circumferential seal against the irregular surface of the DWPF melter pour spout.

2) The expanding ring concept is simple because it only requires temperature for activation and does not require complicated mechanical tooling to install.

3) Radial expansions of up to $4.8 \mathrm{~mm}$ (3/16 inch) were obtained with the currently designed expanding ring. Larger expansions may be possible.

4) The expanding ring supported static loads up to $154 \mathrm{~kg}$ (340 lbs) in laboratory testing using machined surfaces. Higher loads may be required before initiating ring movement on the roughened surface of the melter pour spout.

\section{ACKNOWLEDGMENTS}

The authors would like to express their appreciation to DWPF Engineering for recognizing the importance of this concept and fully supporting its development. This document was prepared in connection with work done under Contract No. DE-AC09-96SR18500 with the U. S. Department of Energy.

\section{REFERENCES}

1. Imrich, K.J., Bickford, D.F., Wicks, G.G., and Hopkins, R.C., 2000, "Resistance of Materials at Elevated Temperatures to the Adherence of Molten Borosilicate Glass," Environmental Issues and Waste Management Technologies, Ceramic Transactions, Vol. 107, American Ceramic Society. 
2. Imrich, K.J., and Iverson, D.C., 2000, "Metallurgical Evaluation of an Inconel 690 Insert from a Radioactive Waste Glass Melter Pour Spout," Environmental Issues and Waste Management Technologies, Ceramic Transactions, Vol. 107, American Ceramic Society.

3. ABAQUS/Standard, Version 6.2, ABAQUS, Inc., Pawtucket, Rhode Island.

4. Venkatesh, V., and Rack, H.J., 1999, "Influence of Microstructural Instabilities on Elevated Temperature Creep Deformation of Inconel 690," Materials Science and Technology, Vol. 15.

5. Isoard, V., 1995, "Thermo-Mechanical Stability of Inconel 690 at Elevated Temperatures," M.S. Thesis, Clemson University, Clemson, SC. 